\title{
The Study of Generic Patterns of Mission and Vision Statements of the Universities
}

\author{
Naveed Nawaz Ahmad* \& Farzana Masroor \\ Department of English, Faculty of Humanities, Air University, Islamabad, Pakistan.
}

Received: September 3, 2020

Published Online: December 21, 2020

\begin{abstract}
Due to the significance of mission and vision statements (MS and VS) in academia across the world, this study aims at analysing generic patterns of MS and VS of universities from four different countries: two belonging to the native users of English language (UK and US) and the other two from non-native contexts (Pakistan and India). The purpose of the study is to investigate the rhetorical patterns in vision and mission statements to uncover structures used to establish universities' global outreach and competitiveness in research and teaching. The data was collected from university websites and analysed through genre-based approach of Move Analysis introduced by Swales (2004) and applied on promotional genres by Bhatia (2004). The overall rhetorical structures of vision and Mission statements comprised of three moves with each move realized through further steps. The findings revealed that text of MS and VS provides the information about the university with an intended purpose of attracting the students by declaring the values, aims, obligations and strategic plans alongside establishing the aspects of global outreach and status in education and research as well as enriching the society and facilitating the individuals with the provision of best resources.
\end{abstract}

Keywords: Generic Patterns, Mission Statement, Vision Statement, Move Analysis, University Websites, Genre Analysis.

\section{Introduction}

Nowadays, universities are more concerned about their strategic planning to compete at the global level regarding research, teaching practices and facilities available. In this regard, the most important tools are mission and vision statements (MS and VS), which the worldwide universities adopted in the early 1980s. University websites, according to Constantinides and Stagno (2011) practice explicit and implicit ways by exploiting basic generic structures to present themselves as recruitment tools of student. Li and Ge (2009) observed that the linguistic structure of texts communicate about the context, and text function that brings some social change in relation to education. Genres that are embedded socio-historically in their contexts (Swales, 2004) are viewed by the participants of particular discourse community on the basis of social interactions (Martin \& León-Pérez, 2014).

In today's global world, the business-oriented approach of educational institutes has motivated the world's prestigious universities to secure a prestigious position among the academia by means of attracting the consumers i.e., students to these academic products using promotional practices in their perspective cultural contexts (Coulter \& Mandell, 2012; Hemsley-Brown, 
2012; Santoro \& Snead, 2013; Yang, 2013). These institutions are surviving due to the everchanging marketing trends that transform them into independent governing bodies and shifting the role of students to consumers (Askehave, 2007; Osman, 2008; Xiong, 2012; Han, 2014; Woodall et al., 2014). Bhatia (2004) suggests that the universities have changed their status from dignified societal institutions to academic centres striving to gain a prestigious status in their respective societies.

Fairclough (1993) views that universities assuming the task of enrolling international students deploy highly promotional discourse by means of enticing linguistic choices to channelize their social purposes. Under such competitive environment, and with a refinement in online advertising tools, Bhatia (2005) states that promotional genres are the most versatile and fast developing areas of discourse. Furthermore, Osman (2008) contends that promotional and advertising culture is a recent trend in academic institutions. The universities mould their academic practices through their generic structures to modernize the socio-academic perspective in academia.

Mission and vision statements (MS \& VS) are viewed as the tools of management for planning to strategize the business or the institution (Bart, 2001). The basic function of MS and VS is to provide the indication about the nature of the business or the institution, how it should be established and work to be the great in field in future. Plenty of researchers have investigated the components and factors of MS and VS to shape them and their connection to the performance and behaviour with a purpose to establish the significance of these statements in different settings.

According to Durna \& Eren (2002), MS and VS is the most important step of strategic planning of academic institutions. Appropriate documentation of MS and VS promise the success of strategic planning of institutions. Strategic planning work to highlight an enduring devotion to the vision and mission of the institute and foster a culture that outlines and supports vision and mission statements (cited in Ozdem, 2011). MS and VS navigate every action of institutions and their productions. Thus, these decisions are crucial and require a careful planning before any decision for the implementation and regulation of other activities of academic organizations (Akgemci, 2007; Ozdem, 2011).

\subsection{Mission and Vision Statement}

MS and VS are considered as the presenter of ideology and institutional culture among many different types of documents in the milieu of communal and institutional life (Swales \& Rogers, 1995). According to Raynor (1998), MS and VS express the organizational values and goals and it is of worth significance to analyze. The values shape the institution's culture and also mould the aims (Davis et al., 2007). MS and VS provide guidelines to manufacture decisions, actions and behaviours accordingly. In view of Swales and Rogers (1995), these statements are integral for actions in terms of defining regulations, instructions and procedures.

The mission statement genre includes a variety of texts that appear with different labels, such as Vision and Mission, Our vision, Our mission, Strategic plan, and most of the times Mission statement and Vision statement. These texts possess enough similarities to characterize them as a single genre, though presence of different terminologies and Mission statement is the true label of this genre as it is used most often. MS and VS are short, direct and clear to present the institution and its aims and goals directly in an effective way to consumers (Swales \& Rogers, 
1995). Morphew and Hartley (2006) stated that the text of these statements is composed of vague and aspirational stock phrases. The text lacks in literary style and conclusions and claims are presented. Present and purposive infinitives such as "to become", "to bring up", and "to get" are used as verb forms (Ozdem, 2011).

Eren (2005) stated about the mission statement that it should be clear, brief, and intense. The brevity and conciseness of a mission statement can help to present the goals, while a vision statement should be focused to present the characteristic features of the organization. The vision statement should facilitate the consumers to understand the organizational culture (cited in Ozdem, 2011).

\subsection{MS and VS as Promotional University Genres}

Swales (2004) stated that genre is studied in relation to communicative purpose, linguistic forms and considering the social context of discourse community. In this regard, Swales and Rodgers (1995) believe that genre analysis is considered incomplete without its socio-cultural context. In the opinion of Martin and Leon-Perez (2014), cultural and contextual tendencies largely influence the persuasive and promotional nature of academic genres. Despite the fact that academia is the centre of interest in the eye of so many genre analyst to understand the discursive knowledge, the study of promotional discourse has attracted the attention of scholars in order to apprehend the commercial edge of academia (Hyland \& Tse, 2009). In the identical vein, Osman (2008) confirms using promotional literature in educational establishment as a latest development.

The genre of mission statement emphasizes on the commitments of universities, defines goals of universities and strives to attain the predetermined academic-professional missions. Universities foreground their academic infrastructure and influential contribution to highlight the significance of actual approaches in relation to their aspirations and commitments to visualize their large-scale goals. A vision statement asks the question that 'What does our business want to become?' A vision statement inspires employees to strive hard and usually results in extraordinary performance, because money-rewards only scarcely persuade employees. It is essential to use tools such as vision statement to increase the motivation of the working people in the organization. MS and VS of universities function as public announcements of their purpose, goals, and values.

The studies of Davies and Glaister (1997), and Kotler and Murphy (1981) on MS and VS start in the beginning of 1980s. On mission statement, scholars like Cochran and David (1986), Firmin and Gilson (2010), Morphew and Hartley (2006), and Seeber et al. (2017) have mostly focused the content, goals, their relation to institutional status (i.e., private or public), and external factors. As far as vision statement is concerned, a limited literature is available, the study of private and public universities' vision statement in relation to differentiation of the contents (Efe \& Ozer, 2015).

Most of those researches, however, have been on businesses, and the research in academia was centred on secondary schools. An overview of the literature confirmed that the research on universities' strategic plans was limited. The method and the content material of MS and VS are vital for the effectiveness of the strategic plan. The present study analyses the structural patterns of MS and VS. Previous studies were carried out on discourse level by means of content analysis and there is scarcity of literature in terms of genre analysis of this promotional 
academic genre. This study aims to analysis genre of MS and VS by means of genre theory to explore the communicative purpose and rhetorical structure of the text cross culturally to amplify the sample of previous works. The study sets out to explore the generic structures of MS and VS of universities with particular reference to move analysis. The study is basically genre analysis of text structures, rhetorical moves, and communicative functions of the "MS and VS" section on the homepage of universities.

\section{Theoretical Approach: From Register to Genre}

In English for Specific Purposes (ESP) need analysis, the description of the nature of language has been the prospective area for the learners to be mastered. ESP has been studied using three approaches of language description has been used in ESP since 1960. At sentence level, register analysis is being used in order to explore differences of language and vocabulary. Register analysis lacks in relation to the explanation of linguistic features in some particular variety of language. Discourse analysis later on replaced register analysis. The focus of discourse analysis approach was to investigate the sentences in their socio-cultural context to identify related communicative events. Bhatia (1993) criticized the approach for its inadequacy to explain the relationship of constraints with the conventions. These constraints and conventions are fulfilled by the members of that discourse community. Swales (1990) defined the discourse community as a group who follow specific patterns of communication, i.e., a set of conventions and these conventions are used on the part of writers to frame the text within constraints (Bhatia, 1993). If there is any kind of violation on the part of these constraints, the nature of text in relation to some specific genre will be changed.

Genre analysis has offered an important framework in relation to the research on aspects of writing and also it has pedagogical applications in relation to teaching and learning. Genre is defined by Martin (1984) in somewhat brief but comprehensively as, "Genre is a staged, goaloriented, purposeful activity in which speakers engage as members of specific culture', (p. 25). Genre was given focus in the 90s in applied linguistics. Swales (1990) provided a detailed and comprehensive definition of genre in the field of ESP, that "a genre comprises a class of communicative events, the members of which share some set of communicative purposes. These purposes are recognized by the expert members of the parent discourse community, and thereby constitute the rationale for the genre. This rational shape the schematic structure of discourse and influences and constrains choice of content and style" (p. 58).

Stating about the nature as well as scope of genre, Bhatia (1993) was of the view that genre is an instance of continuous development of specific communicative purpose under the particular conventions of linguistic and discourse resources. There are variations of genres in relation to complexity, communicative purpose and mode of expression within the discourse communities. Connor (2002) remarked on contrastive rhetoric that it investigates similarities and differences in relation to language and culture across contexts. In relation to genre analysis, text is considered as functional unit in terms of cultural contexts. Present study investigates the generic patterns of MS and VS of universities of four countries (Pakistan, India, United Kingdom and United States). The analysis of the move structure and subsequent steps is carried out by applying Bhatia (2004) and Swales (2004) models.

\section{Research Methodology}

The corpus of the study was comprised of 80 universities' MS and VS. The selection of these 
universities are based on the ranking of top universities' QS World Ranking for the year 2018 and 2019. According to this ranking, top 20 universities from each country were selected. Genre-based move model established by Swales (2004) and Bhatia (1993) was used for generic description of the data. Genre analysis was conducted in terms of identification of rhetorical structures or it can be called as structural move analysis. A move can be defined as a shift in the information flow, a change in topic, or in information being covered. Many scholars attempted to define a move, such as Holmes (1997) defined it as, "a segment of text that is shaped and constrained by a specific communicative function" (p. 235). Dudley-Evans and StJohn (1998) stated, "a 'move' is a unit that relates both to the writer's purpose and to the extent that $\mathrm{s} / \mathrm{he}$ wishes to communicate. A 'step' is a lower-level text unit than the move that provides a detailed perspective on the options open to the writer in setting out the moves in the introduction (p. 89)". Swales and Feak (2012), too, defined move as "a defined and bounded communicative act that is designed to achieve one main communicative objective. Because it is a functional category the length of a move can range from a single finite clause to several paragraphs (p. 35).”

Henry and Roseberry (2001) stated that move analysis is significant for different reasons as it provides the patterns of text organization, distinguishes linguistics features of communicative purpose of the text and it connects the text and linguistics features in terms of social context. Ding (2007) held the idea that moves are semantic and functional units of texts, so these are significant in carrying out genre analysis. Being the building blocks of genre, move helps to identify the communicative purposes of the text. Methodically, identifying text pattern and discourse structure of the text is somewhat help to spot a move that typify a genre and describe how the communicative purpose is understood. Such analysis needs a careful manual coding of each text. Each text of MS and VS was subjected to individual examination to identify the rhetorical patterns and moves/steps present in the text. Each move/step then was cross validated again in the whole data set of MS and VS. To check the reliability of the results and identification of moves and steps in the data set, inter coder reliability check was used. Intercoder reliability, also called as inter-coder, or inter-rater agreement, is used on the part of independent researchers (coders) to analyze the same texts using identical coding scheme to get the desired results.

A researcher with prior knowledge in genre analysis was asked to analyze $1 / 3$ of the data set to check the results and analysis. It appeared that around 88\% results regarding identification of the moves and step were the same as those of researchers' results. The sequence of the moves and their realization in the data set was done later accordingly. There appear some differences in naming the moves and the steps but the overall results of the analysis were similar in realization of the moves and the steps. After the realization of move and steps in MS and VS genre, the pattern of move occurrence and sequence was addressed to elaborate the characteristics of the genre accordingly to constitute MS and VS genre as promotional academic genre.

\section{Data and Analysis}

Genres are defined based on communicative purposes they provide and are realized using moves that reveal the expectation of intended audience in respect of content and format (Swales, 1990; Bhatia, 2004). Text patterns and discourse structures are used to identify moves that provide the communicative purpose of the genre. For the purpose of the analysis, moves were realized by careful reading of each text and then each move was labelled using manual 
coding accordingly. The data set of MS and VS comprising 80 universities from four contexts was subjected to detailed analysis of the moves.

The investigation of "MS and VS" section in the university websites discloses that there are 03 moves naming "Expressing Institutional Aspirations", "Expressing Institutional Commitments and Goals", and "Building Nexus". Among these, two of the moves (Move 1 and 2) are obligatory and present in almost all of the university websites in the data set, the remaining one is optional, that it is present in some universities' MS and VS but absent in others. The moves and their subsequent steps are provided in table-1 below:

Table-1: Description of Moves and Steps

\begin{tabular}{|l|l|l|}
\hline Sr. No. & Move & Steps \\
\hline & & 1.1 Achieving higher status in Academia \\
Move 1 & Expressing institutional & 1.2 Attaining leading role and excellence \\
& Aspiration & 1.3 Providing resources to achieve excellence \\
& & 1.4 Facilitating students \\
& & 1.5 Facilitating and empowering faculty \\
\hline \multirow{2}{*}{ Move 2 } & Expressing institutional & 2.1 Declaring Commitments and goals \\
& Commitments and Goals & 2.2 Showing Commitment to achieve Excellence \\
\hline \multirow{3}{*}{ Move 3 } & \multirow{2}{*}{ Capturing the Market } & 3.1 Establishing and Nurturing relationships \\
& & 3.2 Bridging Gap \\
\hline
\end{tabular}

\section{1. $\quad$ Expressing Institutional Aspirations}

This move particularly defines the vision of the university by describing the distinctive features of achieving excellence and mentioning of resources and facilities available at the university. Moreover, the move provides an indication about the current status and future aspiration of achieving excellence in all the spheres of academia. The moves also highlight the efforts on the part of institution in providing "opportunities" and services for high quality education and research facilities available at campus. The communicative purpose of the move "Expressing Institutional Aspirations" is explained in the following sub-steps.

\subsubsection{Achieving Higher Status in Academia}

The universities aspire to achieve the distinguished status among all other academic and research institutions nationally and internationally. "Achieving a higher status in the academia" proclaims the vision and mission statement of the institution, locally as well as globally. The instances from the data set show that the very step appears in the data of Pakistani and Indian universities as being part of vision statement proclaiming about securing higher ranks. In the data set of the UK and US, the analysis shows some variation as it also appears in the mission statement of some universities.

The examples in the table- 2 below reveal that MS and VS of the universities express its aspiration regarding achieving a distinguished status among other institutions of same prestige at local as well as global level. The bold and italic expressions indicate the universities' aspiration of achieving higher ranks and becoming leading institution. The examples from the data set are as follows: 
Table-2: Achieving Higher Status in Academia

\begin{tabular}{|c|c|c|}
\hline University & Description & Target \\
\hline MS_Anna_IND & $\begin{array}{l}\text { Anna University shall strive towards a World } \\
\text { Class Institution by producing professionals with } \\
\text { high technical knowledge, professional skills and } \\
\text { ethical values. }\end{array}$ & $\begin{array}{l}\text { Achieving higher } \\
\text { status in Academia }\end{array}$ \\
\hline MS_AU_PAK & $\begin{array}{l}\text { Air University aspires to be among the leading national } \\
\text { universities, excelling in teaching, learning, research, } \\
\text { innovation and public service. }\end{array}$ & $\begin{array}{l}\text { Achieving } \\
\text { distinguished status } \\
\text { in academia }\end{array}$ \\
\hline \multirow{2}{*}{$\begin{array}{l}\text { MS_Birmingha } \\
\text { m_UK }\end{array}$} & $\begin{array}{l}\text { More than a century after the University of Birmingham } \\
\text {............remain committed to ensuring our national } \\
\text { and global influence while remaining at the heart of the } \\
\text { city's renaissance. }\end{array}$ & $\begin{array}{l}\text { a: Establishing a } \\
\text { distinguished status. } \\
\text { b: Achieving higher } \\
\text { status in academia }\end{array}$ \\
\hline & $\begin{array}{l}\text {.........This purposeful, pragmatic and pioneering } \\
\text { approach, ........the civic university, becoming the } \\
\text { standard against which others are measured. }\end{array}$ & $\begin{array}{l}\text { Achieving higher } \\
\text { status in academia }\end{array}$ \\
\hline $\begin{array}{l}\text { MS_Glasgow_ } \\
\text { UK }\end{array}$ & A world-class, world-changing university & $\begin{array}{l}\text { Achieving higher } \\
\text { status in academia }\end{array}$ \\
\hline MS_NYU_US & $\begin{array}{l}\text { New York University's mission is to be a top quality } \\
\text { international centre of scholarship, teaching and research. }\end{array}$ & $\begin{array}{l}\text { Achieving higher } \\
\text { status in academia }\end{array}$ \\
\hline
\end{tabular}

\subsubsection{Attaining Leading Role and Excellence}

Universities aim at being considered as the leaders in education and research as well as other spheres of academia. "Attaining leading role and Excellence" describes the hope of universities to be recognized as leaders in the specialized fields of education and research. The data set shows that this step is part of mission statement of universities as it is declared as aim and goal of the institution, but it varies as the data set of Indian universities shows it being stated in Vision statement. The instances from the data set are given below:

Table-3: Attaining Leading Role and Excellence

\begin{tabular}{|l|l|l|}
\hline University & Description & Target \\
\hline MS_IITB_IND & $\begin{array}{l}\text { To be a leading global technology university that provides } \\
\text { a transformative education to create leaders and innovators } \\
\text { and generates new knowledge for society and industry. }\end{array}$ & $\begin{array}{l}\text { Attaining } \\
\text { Leading role in } \\
\text { Academia }\end{array}$ \\
\hline MS_IIT-KGP_IND & $\begin{array}{l}\text { To be a centre of excellence in education and research, } \\
\text { producing global leaders in science, technology and } \\
\text { management. }\end{array}$ & $\begin{array}{l}\text { attaining } \\
\text { leading role and } \\
\text { excellence }\end{array}$ \\
\hline MS_LUMS_PAK & $\begin{array}{l}\text { LUMS aspires to achieve excellence and national and } \\
\text { international leadership through unparalleled teaching } \\
\text { and research,..........the critical needs of society. }\end{array}$ & $\begin{array}{l}\text { Attaining } \\
\text { leading role and } \\
\text { excellence }\end{array}$ \\
\hline MS_Michigan_US & $\begin{array}{l}\text { The mission of the University of Michigan is to serve the } \\
\text { people of Michigan and the world through pre-eminence } \\
\text { in creating, communicating, preserving and ........, and in } \\
\text { developing leaders and citizens who will challenge the } \\
\text { present and enrich the future. }\end{array}$ & $\begin{array}{l}\text { Attaining } \\
\text { leading role and } \\
\text { excellence }\end{array}$ \\
\hline
\end{tabular}

"Attaining leading role and excellence" expresses universities struggle and aim to be a leading institution in relation to build the skills of leadership through teaching and research. In relation to identification of this move/step, the text is highlighted in the examples to realize a particular communicative function of this sub-move. 


\subsubsection{Providing Resources to Achieve Excellence}

This step describes about the resources provided at campus and how these resources help institutions to achieve higher ranks in academia. This step is observed to be present in the Mission statement of the University. "Providing resources to achieve excellence" highlights the resources in terms of facilities for education and research on the part of universities to bring glory for the institution. Examples are as follows:

Table-4: Providing Resources to Achieve Excellence

\begin{tabular}{|c|c|c|}
\hline University & Description & Target \\
\hline MS_BirlaInstitute_IND & $\begin{array}{l}\text { BITS is dedicated to providing its students with an } \\
\text { education that combines rigorous academic study } \\
\text {........... of a diverse campus community }\end{array}$ & $\begin{array}{l}\text { Providing } \\
\text { Resources to } \\
\text { achieve Excellence }\end{array}$ \\
\hline MS_AU_PAK & $\begin{array}{l}\text {......The University shall stand committed to } \\
\text { creating an environment conducive for attracting } \\
\text { the best students, faculty .........., peaceful and } \\
\text { enlightened society. }\end{array}$ & $\begin{array}{l}\text { 1. Showing } \\
\text { commitments to } \\
\text { achieve excellence } \\
\text { 2. Providing } \\
\text { resources to achieve } \\
\text { excellence }\end{array}$ \\
\hline MS_UOS_PAK & $\begin{array}{l}\text { We believe that our institution best fulfils its role } \\
\text { as an anchor establishment in our community } \\
\text { when: } \\
\text { - We provide opportunities; } \\
\text { - We corroborate democratic institutions; } \\
\text { - We encourage ........liberally; and } \\
\text { We cultivate and sustain intellectuals and } \\
\text { productive citizens of tomorrow ..........ethics and } \\
\text { morality. }\end{array}$ & $\begin{array}{l}\text { Providing resources } \\
\text { to achieve } \\
\text { excellence }\end{array}$ \\
\hline MS_Oxford_UK & $\begin{array}{l}\text { Our mission is to develop, maintain and manage } \\
\text { the University .............and the provision of a } \\
\text { world class research, teaching and learning } \\
\text { environment. }\end{array}$ & $\begin{array}{l}\text { Providing resources } \\
\text { to achieve } \\
\text { excellence }\end{array}$ \\
\hline MS_MIT_US & $\begin{array}{l}\text { Our mission is to provide a high quality, accessible } \\
\text { and affordable education that advances } \\
\text { knowledge and improves lives }\end{array}$ & $\begin{array}{l}\text { providing resources } \\
\text { to achieve academic } \\
\text { excellence ... }\end{array}$ \\
\hline
\end{tabular}

This sub-move presents the available resources at campus to facilitate the students and faculty to achieve excellence in education. Highlighted sections in the examples indicate about the communicative function of the step that universities aspire to provide resource to attain distinguished status.

\subsubsection{Facilitating Students to Achieve Excellence}

This step further classifies the resources provided at campus to students specifically that how they can work with their full zeal and zest to reach higher scales in education and research. The very step basically introduces the facilities of education and research provided to students to work in better environment. The data set shows variations in terms of this step that it appears as part of vision statement in Indian universities but the results are mixed in other three contexts in which it is sometimes part of the mission statement and subsequently vision statement. The instances for this step from data are provided here: 
Table-5: Facilitating Students to Achieve Excellence

\begin{tabular}{|c|c|c|}
\hline University & Description & Target \\
\hline MS_Delhi_IND & $\begin{array}{l}\text { Be an internationally acclaimed University, recognized for } \\
\text { excellence ......... provide the highest quality education to } \\
\text { students, nurture their talent, promote intellectual growth } \\
\text { and shape their personal development }\end{array}$ & \multirow{4}{*}{$\begin{array}{l}\text { Facilitating } \\
\text { students to } \\
\text { achieve } \\
\text { excellence }\end{array}$} \\
\hline MS_PU_PAK & $\begin{array}{l}\text { Our mission is to provide a holistic education as such an } \\
\text { approach has two-fold benefit. The first is that young people } \\
\text { are nurtured to be sensitive, tolerant, humane and capable of } \\
\text { thinking in a creative and critical way }\end{array}$ & \\
\hline MS_Bristol_UK & $\begin{array}{l}\text { Learning: we will admit the students with the best potential. } \\
\text { We will challenge students intellectually and prepare them } \\
\text { for life in the } 21 \text { st century }\end{array}$ & \\
\hline MS_Northwestern_US & $\begin{array}{l}\text { North-western is committed to excellent teaching, } \\
\text { innovative research and the personal and intellectual } \\
\text { growth of its students in a diverse academic community }\end{array}$ & \\
\hline
\end{tabular}

The examples provide the explanation of the communicative purpose of this very step that universities aspire to provide best facilities and resources to students to enjoy excellence in education and research.

\subsubsection{Facilitating and Empowering Faculty}

This step engages the purpose of describing the resources to fulfil the requirements of faculty in provision of better environment and other academic facilities to work for the global impact of the institution. It is attributed as a goal of the institution to facilitate and empower the faculty for better results and development of environment for better research and education. The examples below show the highlights of this step from data set:

Table-6: Facilitating and Empowering Faculty

\begin{tabular}{|c|c|c|}
\hline University & Description & Target \\
\hline $\begin{array}{l}\text { MS_Savitribai_ } \\
\text { IND }\end{array}$ & $\begin{array}{l}\text {.......... and committed to empower its faculty and } \\
\text { students to contribute meaningfully to economic, } \\
\text { technological and social development and progress quote } \\
\text { mission. }\end{array}$ & $\begin{array}{l}\text { Facilitating and } \\
\text { Empowering } \\
\text { Faculty to achieve } \\
\text { excellence }\end{array}$ \\
\hline MS_QAU_PAK & $\begin{array}{l}\text { Ensuring and supporting faculty and staff to continue } \\
\text { their professional and intellectual development. }\end{array}$ & $\begin{array}{l}\text { Empowering } \\
\text { faculty }\end{array}$ \\
\hline $\begin{array}{l}\text { MS_Glasgow_ } \\
\text { UK }\end{array}$ & $\begin{array}{l}\text { To bring inspiring people together and create a world- } \\
\text { class environment for learning and research, empowering } \\
\text { staff and students to discover and share knowledge that } \\
\text { can change the world }\end{array}$ & $\begin{array}{l}\text { Empowering } \\
\text { faculty and students }\end{array}$ \\
\hline MS_NYU_US & $\begin{array}{l}\text { New York University's mission is to be a top quality } \\
\text { international centre of scholarship, teaching and research. } \\
\text { This involves retaining and attracting outstanding } \\
\text { faculty who are leaders in their fields, encouraging them } \\
\text { to create programs that draw outstanding students, and } \\
\text { providing an intellectually rich environment }\end{array}$ & $\begin{array}{l}\text { Facilitating faculty } \\
\text { to achieve } \\
\text { excellence }\end{array}$ \\
\hline
\end{tabular}

These examples express the institutional aspiration in relation to empowering and facilitating faculty to develop a conducive environment and building nexus to improve professional and intellectual development. 


\subsection{Expressing Institutional Commitments and Goals}

Move 2 describes the strategic plans, aims, commitments and dedications on the part of university to achieve in future. Move 2 clarifies the functionality of the university by declaring aims and obligations in provision of amiable facilities to students and by expressing facts and figures in terms of students' enrolment, awards and honours, and other achievements in research and education. The move is further divided into following steps:

\subsubsection{Declaring Commitments and Goals}

"Declaring commitments and goals" states the purpose of mentioning institutional commitments and goals that universities aim to provide by declaring their mission statements. The data set shows that every university aspires to proclaim facilities provided at campus in relation to engaging students and faculty and competing the other institutions to transform the university into a globally acknowledged institution. The examples are provided below according to the universities and context, i.e., Universities from four countries.

Table-7: Declaring Commitments and Goals

\begin{tabular}{|c|c|c|}
\hline University & Description & Target \\
\hline $\begin{array}{l}\text { MS_IIT- } \\
\text { KGP_IND }\end{array}$ & $\begin{array}{l}\text { Mission: The Institute aligns all its activities to serve } \\
\text { national interest and seeks } \\
\text { - To provide broad-based education, helping students } \\
\text {.........in their respective disciplines } \\
\text { - To draw the best expertise in science, technology, } \\
\ldots \ldots . . \text { in these fields } \\
\text { - To imbibe a spirit of entrepreneurship and innovation } \\
\text { in its students } \\
\text { - To undertake sponsored research and provide } \\
\text { consultancy services ...........areas }\end{array}$ & $\begin{array}{l}\text { Declaring } \\
\text { commitments and } \\
\text { goals to achieve } \\
\text { excellence }\end{array}$ \\
\hline & $\begin{array}{l}\text { Its mission shall be to create and disseminate knowledge } \\
\text { through research and creative inquiry, ............... to } \\
\text { enhance society in meaningful and sustainable ways }\end{array}$ & $\begin{array}{l}\text { Declaring } \\
\text { commitments and } \\
\text { goals }\end{array}$ \\
\hline MS_IUB_PAK & $\begin{array}{l}\text { Its mission shall also be to serve students by teaching } \\
\text { them problem solving, leadership and teamwork skills, } \\
\text { and the value of commitment to quality, ethical behaviour } \\
\text { and respect for others. }\end{array}$ & $\begin{array}{l}\text { 1. Declaring } \\
\text { commitments and } \\
\text { goals } \\
\text { 2. Showing } \\
\text { commitments to } \\
\text { achieve excellence }\end{array}$ \\
\hline $\begin{array}{l}\text { MS_Birmingham } \\
\text { _UK }\end{array}$ & $\begin{array}{l}\text { As an institution dedicated to learning, we contribute to } \\
\text { the growth and spread of knowledge and ideas ......; } \\
\text { working with partners ......locally, nationally \& globally. }\end{array}$ & $\begin{array}{l}\text { Declaring } \\
\text { commitment and } \\
\text { goal }\end{array}$ \\
\hline \multirow[b]{2}{*}{$\begin{array}{l}\text { MS_Carnegie- } \\
\text { Mellon_US }\end{array}$} & $\begin{array}{l}\text { To create a transformative educational experience for } \\
\text { students focused on deep disciplinary knowledge; } \\
\text { problem solving; leadership, communication, and } \\
\text { interpersonal skills; and personal health and well-being. }\end{array}$ & \multirow[b]{2}{*}{$\begin{array}{l}\text { Declaring } \\
\text { commitments and } \\
\text { goals }\end{array}$} \\
\hline & $\begin{array}{l}\text { To cultivate a transformative university community } \\
\text { committed to (a) attracting and retaining diverse, world- } \\
\text { class talent, (b) creating a collaborative environment open } \\
\text { to the free exchange of ideas, where research, creativity, } \\
\text { innovation, and entrepreneurship can flourish; and (c) } \\
\text { ensuring individuals can achieve their full potential. }\end{array}$ & \\
\hline
\end{tabular}


These examples from MS and VS provide the indication about communicative purpose of submove "Declaring commitments and goals". The move/step expresses universities' aims and obligations in order to achieve excellence in the fields of education and research.

\subsubsection{Showing Commitment to Achieve Excellence}

Apart from declaring commitments, some institutions express certain aims and obligations to be fulfilled in future as the institution grows on a larger scale to attain higher rank on global scales. The step is classified as a separate one from "Declaring commitments and goals", as the universities from Pakistan and UK show commitments and dedications to be work on in future in relation to declaring aims and goals and it appears as part of vision statement. Universities of India and US do not show anything like commitments as part of their Vision statement.

Table-8: Showing Commitment to Achieve Excellence

\begin{tabular}{|l|l|l|}
\hline University & Description & Target \\
\hline MS_FAST_PAK & $\begin{array}{l}\text { In line with the thrust of our faith and glory of our heritage, we } \\
\text { shall try our best to play an effective and meaningful role in } \\
\text { creating a knowledge based society in Pakistan. This avenue } \\
\text {...... with knowledge driven economy. }\end{array}$ & $\begin{array}{l}\text { Showing } \\
\text { commitment } \\
\text { to achieve } \\
\text { excellence }\end{array}$ \\
\hline MS_LSE_UK & $\begin{array}{l}\text { Our strategy lays out the guiding principles and commitments } \\
\text { that will help us shape the world's future, and achieve our } \\
\text { ambition ........greatest global impact. }\end{array}$ & $\begin{array}{l}\text { Showing } \\
\text { commitment } \\
\text { to achieve } \\
\text { excellence }\end{array}$ \\
\hline MS_QMU_UK & $\begin{array}{l}\text { Dedicated to the public good, we will generate new knowledge, } \\
\text { challenge existing knowledge, and engage locally, nationally } \\
\text { and internationally to create a better world. }\end{array}$ & $\begin{array}{l}\text { Showing } \\
\text { commitment } \\
\text { to achieve } \\
\text { excellence }\end{array}$ \\
\hline
\end{tabular}

UK and Pakistan Universities' MS and VS apart from declaring commitments and obligations express dedications of the institutions to show commitment in order to achieve excellence in different field of academia.

\subsection{Capturing the Market}

Move 3 expresses the universities' interest in establishing the partnership with other institutions to improve the standards of research and providing a healthy interaction and facilities for the scholars around the world. Move 3 is defined as; it declares university's global impact in research and education as well as embraces university's national and local roles to emphasize the university's position and building partnerships with other institutions around the world. Following are the steps of move 3:

\subsubsection{Establishing and Nurturing Relationships}

This step particularly highlights universities' aspirations in building relationships with other universities around the globe to attract students and give a healthy share in terms of societal associations to redefine university status as a globally recognized institution. The purpose of describing about "Establishing and nurturing relationships" in MS and VS is to announce about universities' global reach. The step indicates the collaboration with others institutions around to strengthen the educational and research system. Pakistani universities and Indian universities 
as well lack in expressing values related to establishing and nurturing relationships. The UK and US universities have built an environment of establishing and nurturing relationships around the globe and it is manifested in Mission statements of the institutions of these contexts. Relevant examples are provided below.

Table-9: Establishing and Nurturing Relationships

\begin{tabular}{|l|l|l|}
\hline University & Description & Target \\
\hline MS_IITB_IND & $\begin{array}{l}\text { To collaborate with other academic and research } \\
\text { institutes around the world to strengthen the education } \\
\text { and research ecosystem }\end{array}$ & $\begin{array}{l}\text { Nurturing } \\
\text { relationships }\end{array}$ \\
\hline MS_UOS_PAK & $\begin{array}{l}\text { The University of Sargodha is driven by its vision-a } \\
\text { commitment to forging bold, imaginative, reciprocal, } \\
\text { and sustained engagements with our many } \\
\text { constituent communities, local as well as global }\end{array}$ & $\begin{array}{l}\text { Establishing and } \\
\text { Nurturing } \\
\text { relationships }\end{array}$ \\
\hline MS_Birmingham_UK & $\begin{array}{l}\text { We bring together the people and resources to tackle } \\
\text { the major challenges of our time. We draw ............ } \\
\text { our global reach and reputation. }\end{array}$ & $\begin{array}{l}\text { 1. Bridging gap } \\
\text { 2. Nurturing } \\
\text { relationships }\end{array}$ \\
\hline MS_Columbia_US & $\begin{array}{l}\text { The University recognizes the importance of its } \\
\text { location in New York City and seeks to link its } \\
\text { research and teaching to the vast resources of a great } \\
\text { metropolis. It seeks .........., and to create academic } \\
\text { relationships with many countries and regions. }\end{array}$ & $\begin{array}{l}\text { Establishing and } \\
\text { nurturing } \\
\text { relationships }\end{array}$ \\
\hline
\end{tabular}

The communicative purpose of the move/step is italicized and bold in the examples that express universities' struggle to achieve excellence and build relationships around the world to meet the global challenges in education, research and other academic areas.

\subsubsection{Bridging Gap}

This step expresses the universities' intentions to build relationships and bridging the gaps between the faculty and students by facilitating them with prerequisites of education, research and improving teaching and learning environment. "Bridging gap" defines the nature of institution in building links with the community to bring students all around the globe closer in achieving the excellence in research and education. Mission statement of the universities does not express certain bondages separately in terms of bridging gaps but the focus is on expressing and establishing relationships all around to provide healthy environment of education and research.

Table-10: Bridging the Gap

\begin{tabular}{|c|c|c|}
\hline University & Description & Target \\
\hline MS_Delhi_IND & $\begin{array}{l}\text { The Vision and Mission statements of the University of Delhi } \\
\ldots \ldots . . . \ldots . . . \text { the whole world by acting as a bridge between } \\
\text { the University community and the community at large }\end{array}$ & Bridging Gap \\
\hline MS_NUST_PAK & $\begin{array}{l}\text { NUST, ..............hopes to bridge this gap through School } \\
\text { of Natural Sciences (SNS). }\end{array}$ & Bridging Gap \\
\hline MS_Sheffield_UK & $\begin{array}{l}\text { Building a community by continuing to develop an exceptional } \\
\text { experience, through engagement and support }\end{array}$ & Bridging gap \\
\hline MS_Brown_US & $\begin{array}{l}\text {........ We do this through a partnership of students and } \\
\text { teachers in a unified community known as a university- } \\
\text { college. }\end{array}$ & Bridging gap \\
\hline
\end{tabular}


This move/step shows that universities are aspirant in developing links with the wider community around the globe to provide assistance to the society in order to make it sustainable in all its branches.

\subsubsection{Building Human Capital}

The purpose of expressing this step in MS and VS is to provide an indication about the institution that it is working in benefitting the society directly by nurturing relationships locally, nationally and globally to bring people closer in terms of associating research activities and improving the skills of students and faculty to foster the research skills particularly and leadership potential of graduates so that they may exercise these skills professionally to improve the condition of society and community as well as of individuals. "Building human capital" defines the aspirations and commitments of universities to proclaim about the activities of institutions in relation to developing relationships of universities with the local as well as global market. The purpose of the sub-move is to improve the quality of life and building economically self-sufficient societies all around by providing opportunities to the students and engaging faculty, alumni and the community for the betterment of humankind. The examples from the data set are provided in table-11 below.

Table-11: Building Human Capital

\begin{tabular}{|c|c|c|}
\hline University & Description & Target \\
\hline MS_IITD_IND & $\begin{array}{l}\text { To develop human potential to its fullest extent .......... a range } \\
\text { of professions. }\end{array}$ & $\begin{array}{l}\text { Building } \\
\text { human capital }\end{array}$ \\
\hline \multirow[t]{2}{*}{ MS_PU_PAK } & $\begin{array}{l}\text {... The second is, that armed with a sense of history and equipped } \\
\text { with knowledge and expertise, the graduates whom we send out } \\
\text { into the world are in a better position to develop their leadership } \\
\text { potential and make a positive contribution to public life. }\end{array}$ & $\begin{array}{l}\text { Building } \\
\text { human capital }\end{array}$ \\
\hline & $\begin{array}{l}\text { We hope that understanding as they do; their role in the wider } \\
\text { community of human kind and responsible to it, their action } \\
\text {........education }\end{array}$ & $\begin{array}{l}\text { Building } \\
\text { human capital }\end{array}$ \\
\hline $\begin{array}{l}\text { MS_St.Andrews } \\
\text { _UK }\end{array}$ & $\begin{array}{l}\text { To be a world-recognized, global community of scholars who } \\
\text { engage with students, ................on social and environmental } \\
\text { accounting and accountability as a way to envisage and enable } \\
\text { a more sustainable society. Mobilising ..........more sustainable } \\
\text { society. }\end{array}$ & $\begin{array}{l}\text { Building } \\
\text { human capital }\end{array}$ \\
\hline MS_Cornell_US & $\begin{array}{l}\text { Cornell also aims, through public service, to enhance the lives } \\
\text { and livelihoods of students, ….... of New York } \\
\ldots . . . \ldots \ldots . . . \text { around the world }\end{array}$ & $\begin{array}{l}\text { Building } \\
\text { human capital }\end{array}$ \\
\hline
\end{tabular}

The universities aim to develop the human potential in order to build a more sustainable society by providing maximum opportunities and facilities to the students. It is done in a way to generate and disseminate knowledge and pragmatism so that they can make a positive contribution in the public life. The communicative function is provided in the above-mentioned examples in the table.

\section{Discussion and Findings}

The text of MS and VS includes three move structures comprising of further steps of each move that provide and define the functions of each move in stating mission and vision of the universities. The moves and steps proclaim about the primary concerns of universities by 
declaring the purposes and how they act to achieve the major obligations and commitments of the universities. The functions of moves are defined on the basis of steps of each move and moves are entitled to be obligatory or optional by the occurrence of steps in relation to each move in the text. Table 12 presents the description of steps and their communicative function in relation to each move through analysis of text of MS and VS.

Table-12: Steps and their Function

\begin{tabular}{|c|c|}
\hline Steps & unctions \\
\hline $\begin{array}{l}\text { 1.1 Achieving higher } \\
\text { status in Academia }\end{array}$ & $\begin{array}{l}\text { tates institutional vision in a way to proclaim distinguished status among } \\
\text { ther institutions }\end{array}$ \\
\hline $\begin{array}{l}\text { 1.2 Attaining leading } \\
\text { role and excellence }\end{array}$ & $\begin{array}{l}\text { Expresses institutions' desire to accomplish the status of the institution as } \\
\text { a leader }\end{array}$ \\
\hline $\begin{array}{l}\text { 1.3 Providing resources } \\
\text { to achieve } \\
\text { excellence }\end{array}$ & $\begin{array}{l}\text { Communicates the reader about the available facilities at campus in } \\
\text { relation to branding education and research }\end{array}$ \\
\hline 1.4 Facilitating students & $\begin{array}{l}\text { ers by stating the resources available for } \\
\text { dies }\end{array}$ \\
\hline $\begin{array}{r}1.5 \text { Facili } \\
\text { empo }\end{array}$ & $\begin{array}{l}\text { Ind obligations in relation to empowering } \\
\text { ts in education and research }\end{array}$ \\
\hline $\begin{array}{l}2.1 \text { Declaring } \\
\text { commitments and } \\
\text { Goals }\end{array}$ & $\begin{array}{l}\text { uncing goals to achieve } \\
\text { to compete the global }\end{array}$ \\
\hline $\begin{array}{l}\text { 2.2 Showing } \\
\text { commitment to } \\
\text { achieve Excellence }\end{array}$ & $\begin{array}{l}\text { Announces dedication on the part of institution to achieve higher ranks in } \\
\text { academia }\end{array}$ \\
\hline $\begin{array}{l}\text { 3.1 Establishing and } \\
\text { Nurturing } \\
\text { Relationships }\end{array}$ & $\begin{array}{l}\text { Catches the readers' attention by proclaiming about the links locally as } \\
\text { well as globally to target the market all around and building a relationship } \\
\text { with other institutions of same prestige and value to engage the masses as } \\
\text { well as industries to enhance and assist the system economically }\end{array}$ \\
\hline 3.2 Bridging Gap & $\begin{array}{l}\text { States the nurturing relationships between faculty and students as well as } \\
\text { bringing all the stakeholders of the educational market close to each other } \\
\text { to establish lasting relationships and improve financial scenario across the } \\
\text { globe. }\end{array}$ \\
\hline $\begin{array}{l}\text { 3.3 Building Human } \\
\text { Capital }\end{array}$ & $\begin{array}{l}\text { Expresses institutional efforts to provide the graduates of highest skills } \\
\text { and calibre that may contribute to world's economy and lead the society } \\
\text { in particular to build an environment of peace and harmony among all the } \\
\text { individuals locally, nationally and globally. It also states the universities' } \\
\text { efforts to provide skill-based learning, education and research. }\end{array}$ \\
\hline
\end{tabular}

Move 1 "Expressing institutional Aspiration" is explored in the text on the basis of further classification of move into sub-steps including, achieving higher status in academia, attaining leading role and excellence, providing resources to achieve excellence, facilitating students, Facilitating and empowering faculty. Step 1 "Achieving higher status in academia" states that universities feel pride in proclaiming about the status of institution in comparison to other institutes nationally as well as globally.

In stating such claims about the institution, it builds the repute of the university and gets students' attention in relation to choosing the institution for studies. Moreover, universities engage the students across the globe by offering and stating more evidence and factual information. Step 2 "Attaining leading role and excellence", Step 3 "Providing resources to achieve excellence", Step 4 "Facilitating students", and Step 5 "Facilitating and empowering 
faculty" publicize about the institutional efforts to achieve excellence in education and research by stating these aspirations.

Move 2 "Expressing institutional Commitments and Goals" highlight the aims, obligations and dedications of the universities to attain higher ranks by the fulfilment of these obligations. Move 2 provides information to students and other stakeholders that how universities are progressing through and what they aim to achieve in relation to attaining higher status, excellence in academia, provision of resources to students and faculty. The move is classified further into two steps, "Declaring commitments and goals", and "Showing commitment to achieve excellence" to express the obligations to be achieved.

The Move 3 "Building Nexus/Capturing the Market" states the mission of universities in order to build healthy relationships particularly with the local market and globally as well to address the economic and societal behaviour by investing on the masses, i.e., students, faculty and other professionals. The move functions on the basis of further steps to highlight the goals in relation to nurturing positive links all around to portray a positive image of the institution. The steps include, "Establishing and nurturing relationships", "Bridging gap", "Building human capital" and show the nexus with the local institutions and the global partners to improve the condition of the individuals.

The analysis was done using inter-coder reliability. The frequencies of moves and steps of the data set were recorded by the researcher manually. Another researcher, that have enough knowledge of genre analysis helped in coding the data as he was asked to code around $25 \%$ of the corpus, i.e., 5 texts of MS and VS of each context among the four selected. The inter-coder reliability reached around $88 \%$ on the basis of agreed coding in relation to total coding of the data. It was appeared that the generic patterns of MS and VS show obligatory, optional and conventional moves/steps in the structure of text.

Table-13: Occurrence of Moves/Steps and their Types

\begin{tabular}{|c|c|c|c|}
\hline No. & Move Description & Steps & Nature \\
\hline \multirow{5}{*}{ Move 1} & \multirow{5}{*}{$\begin{array}{l}\text { Expressing institutional } \\
\text { aspiration }\end{array}$} & 1.1 Achieving higher status in academia (43) & \multirow{8}{*}{ Obligatory } \\
\hline & & 1.2 Attaining leading role and excellence (28) & \\
\hline & & $\begin{array}{l}\text { 1.3 Providing resources to achieve excellence } \\
\text { (24) }\end{array}$ & \\
\hline & & 1.4 Facilitating students $(21)$ & \\
\hline & & Facilitating and empowering faculty (08) & \\
\hline \multirow[b]{2}{*}{ Move 2} & \multirow[b]{2}{*}{$\begin{array}{l}\text { Expressing institutional } \\
\text { commitments and goals }\end{array}$} & 2.1 Declaring commitments and goals (42) & \\
\hline & & $\begin{array}{l}2.2 \text { Showing commitment to achieve } \\
\text { excellence }\end{array}$ & \\
\hline \multirow{3}{*}{ Move 3} & \multirow{3}{*}{ Capturing the market } & $\begin{array}{l}\text { 3.1 Establishing and nurturing relationships } \\
\text { (30) }\end{array}$ & \\
\hline & & 3.2 Bridging gap (10) & Conventional \\
\hline & & 3.3. Building human capital (29) & Obligatory \\
\hline
\end{tabular}

Moves are classified into obligatory, optional and conventional on the basis of occurrence of sub-steps in the data in relation to particular move that step represents. Table 6 represents the nature of moves and frequencies. Classification of moves into obligatory, optional and conventional is decided on the basis of frequency of occurrence. If a particular move/step occurred in almost every MS and VS (i.e., the count is $80-100 \%$ ); then it was considered as 
obligatory. If a move/step appeared quite often in MS and VS genre (i.e., the score is between $60-80 \%$ ), it was labelled as conventional, and if the occurrence was less frequent (i.e., the frequency is less than 60\%) was labelled as optional. It was observed that Move1 and 2 have maximum frequency on the basis of occurrence of steps and Move 3 has fewer occurrences. It is believed that move 1 and 2 are part of almost all the MS and VS in the data set.

Genre analysis is a process of identifying/analysing the similarities and differences of a particular genre on the basis of its communicative purpose, rhetorical structure and linguistic choices. According to Hyland (2005) "Genres are community resources which allow users to create and read texts with some assurance" (p. 33). MS and VS genre is identified as promotional genre on the basis of mentioned characteristics as it has scholars, researchers and most importantly students as the participants of academic promotional genres. The product of all the academic promotional genres is the informative rhetorical acts in the text. There are some differences in MS and VS on the part of specific and common communicative purpose of this genre, yet these statements are used for the same overall purpose to introduce the global consumers with the goals, commitment and future plans of the university to attract them and provide them with some basic information about the strategic vision of university.

The present genre set, in comparison to the student prospectus genre (Askehave, 2007), highlights some moves such as 'Expressing institutional aspirations and commitments.' In the same streamline as mentioned by Osman (2008), some moves and their communicative purpose of university brochures is similar to the present study, i.e., the vision and mission statement and the available facilities. Moreover, in a study conducted by Yang (2013) on a section "Why Choose US" of university websites, the moves "establishing a distinguished status", "ensuring excellent teaching quality", "presenting a leading role in research", and "offering attractive incentives" are also present in MS and VS genre in the present study. In comparison to the study of Atai and Asdonia (2016) on introductory genre set of universities, the present study shared same patterns of the communicative purpose in the realization of the moves such as "Global status", "Sources of reputation", and "Services and supports" in relation to the move 1 , move 2 and their steps.

Dincer (2004) expresses the purpose of mission and vision statements for an organization. MS expresses about the reason of existence of an organization and identifies the aims and objectives. VS, alongside communicates those aims and objectives of the organization in the future run to achieve higher goals and present the image of the institution (cited in Ozdem, 2011). The overall communicative purpose of MS and VS of universities is to state the commitments by declaring aims, objectives, obligations and goals to compete the global academia in education and research. The global outreach is more visible in vision statement as to achieve higher global status in teaching, learning facilities and leading role in research as well as provision of friendly environment.

The search for global value and status in the education and research is basic thought and message underlying the MS and VS. Some of the general findings of MS and VS of this study are; the mission statements tend to be longer than the vision statements. There is a trend towards the global influence in the vision statements. There is an overall push for the research and quality teaching. The universities were focused on individuals (students, faculty, staff), research resources and global outreach. The universities are building relationship worldwide in the areas of research. 


\section{Conclusion}

The study draws upon the concept of promotional academic genre in professional settings. The study was attempted to explore the generic structure employed in MS and VS present on official websites of universities of 04 countries. Hyland and Tse (2009) remarked on academic genres as informative as well as promotional because these genres function as to represent, advocate and anticipate some features of the given information. The promotional academic genre of MS and VS disseminate the information about universities' commitments, goal, obligations and strategic plans regarding education and research to achieve global impetus among higher education institutions. According to Hyland (2006) genres of academia present larger structures and they function in colonies. MS and VS genre is broadly declared as part of strategic vision of universities and this is again dependant on other set of text on university websites that they appear in the sections of "about us" or "introduction of university". It is evident then that MS and VS genre is intertextually imbedded in the professional academic context of online universities' websites.

Bhatia (2004) defined some characteristics of promotional genre that it has specific communicative purpose, same product and participants and rhetorical information and acts. Investigating the generic structure of text of MS and VS genre, it was revealed that this promotional genre was distinct in patterns of moves as there was a shared communicative purpose such as move 1 "Expressing Institutional Aspirations" that overlap with move 2 "Expressing Institutional Commitments and Goals" while exploring the text on level of steps of move 1 and 2. These generic patterns using descriptive and persuasive linguistic attribution of text provide the information about the university with an intended purpose of attracting the students by declaring the values, aims, obligations and strategic plans alongside establishing the aspects of global outreach and status in education and research as well as enriching the society and facilitating the individuals with the provision of best resources.

To investigate the generic structure of MS and VS genre, the move analysis was conducted to interpret the communicative practices of the text of websites. It was highlighted that three move structures appeared in the text of MS and VS genre. Move 1 delineates the vision of the university by describing the current status and future aspiration of achieving excellence and mentioning of resources and facilities available at the university. Move 2 assures to attain higher ranks by the fulfilment of goals and objectives of the institutions. Move 3 functions to highlight the goals in relation to nurturing positive links all around to portray constructive image of the institution to address the economic and societal behaviour by investing on the masses, i.e., students, faculty and other professionals. Among the three moves, Move 1, and Move 2 are considered obligatory in terms of occurrence of these moves and their steps in the text. The frequency count of move 1(65) and move 2(57) also revealed that these moves are obligatory in the text and move 3(33) is optional because of less frequency count in the text of data set of MS and VS genre.

The present research was carried out to explore the conventional textual organization of MS and VS using move analysis model of genre theory. The findings of this work highlighted the rhetorical nature of this genre and provided a start point for future prospective researchers in Genre analysis of promotional academic genres. Since this study is the preliminary in nature on MS and VS genre of universities, several researchers can be carried out in future using different corpus and genre model as well as comparative investigation of generic patterns cross culturally. Moreover, the comparative investigations on cross cultural and contextual grounds 
among native and non-native countries of English to explore the differences and similarities of linguistic constructions of the text and lexico-grammatical choices because of different socio cultural and academic contexts.

The researchers are encouraged to conduct the case studies of individual university websites by exploring all the sections and sub-sections. The comparison of corpus from different institutional websites (distinction of the universities may be done on the nature of the institution, i.e., public, private and distance learning) may also be investigated. Such studies would involve the interests of professionals in the data mining as they may use programming to cull larger amount of data in the form of electronic texts efficiently. In the framework of genre analysis, the investigation of multi-modality and intertextuality may also be explored in the rhetorical moves of websites. It is further suggested that studies may be carried out on other genres of higher education institutions using larger data set of the universities. A comparative study of Pakistani and foreign universities may be conducted to explore cross-cultural perspective in the area.

The study is also significant for members of academic community. It may assist the prospective students to find the required information about the universities. For instance, it helps postgraduate researchers to find the academic institutions with higher status and all the facilities available for research. It would be of great assistance for University administrations in defining the purpose and future plans for distinctive strategies to exhibit global outreach of the institutions. The current study also highlights new web genres that enhance communication among members of academic communities. In this regard, the study is substantial for future researchers to work on rhetorical structure of text other than academic orientation to strengthen the marketing endeavour in online resources.

\section{References}

Akgemci, T. (2007). Strategic management. Gazi Kitapevi.

Askehave, I. (2007). The impact of marketization on higher education genres-the international student prospectus as a case in point. Discourse Studies, 9(6), 723-742. https://doi.org/10.1177/1461445607082576

Atai, M. R., \& Asadnia, F. (2016). The prestigious world university on its homepage: the promotional academic genre of overview. Iranian Journal of Applied Linguistics, 19(1), 1-34. https://ijal.khu.ac.ir/article-1-2621-fa.html

Bart C. K. (2001). Exploring the application of mission statements on the world wide web. Internet Research, 11(4), 360-369. https://doi.org/10.1108/10662240110402812

Bhatia, V. K. (2004). Worlds of Written Discourse. Continuum.

Bhatia, V. K. (2005). Generic patterns in promotional discourse. In H. Halmari and T. Virtanen (Eds.), Persuasion across genres. John Benjamins.

Cochran, D. \& David, F. (1986). Communication effectiveness of organizational mission statements. Journal of Applied Communication Research, 14(2), 108-118. https://doi.org/10.1080/00909888609360308

Connor, U. (2002). New directions in contrastive rhetoric. TESOL Quarterly, 36(4), 493-510. https://doi.org/10.2307/3588238

Constantinides, E. \& Stagno, M. C. Z. (2011). Potential of the social media as instruments of higher education marketing: a segmentation study. Journal of Marketing for Higher Education, 21(1), 7-24. https://doi.org/10.1080/08841241.2011.573593 
Coulter, X. \& Mandell, A. (2012). Adult higher education: are we moving in the wrong direction? The Journal of Continuing Higher Education, 60(1), 40-42. https://doi.org/10.1080/07377363.2012.649133

Davies, S. \& Glaister, K. (1997). Business school mission statements: the bland leading the bland? Long Range Planning, 30(4), 594-604. https://doi.org/10.1016/S00246301(97)00038-1

Davis, J., Ruhe, J., Lee, M., \& Rajadhyaksha, U. (2007). Mission possible: do school mission statements work? Journal of Business Ethics, 70, 99-110. https://link.springer.com/article/10.1007/s10551-006-9076-7

Ding, H. (2007). Genre analysis of personal statements: Analysis of moves in application essays to medical and dental schools. English for Specific Purposes, 26(3), 368-392. https://doi.org/10.1016/j.esp.2006.09.004

Dudley-Evans, T. \& St-John, M. J. (1998). Developments in English for specific purposes: a multi-disciplinary approach. Cambridge University.

Efe, I. \& Ozer, O. (2015). A corpus-based discourse analysis of the vision and mission statements of universities in Turkey. Higher Education Research and Development, 34(6), 1110-1122. https://doi.org/10.1080/07294360.2015.1070127

Fairclough, N. (1993). Critical discourse analysis and the marketization of public discourse: the universities. Discourse \& Society 4(2), 133-168. https://doi.org/10.1177/0957926593004002002

Firmin, M. W., \& Gilson, K. M. (2010). Mission statement analysis of CCCU member institutions. Christian Higher Education, 9(1), 60-70. https://doi.org/10.1080/15363750903181922

Han, Z. (2014). The marketization of public discourse: the Chinese universities. Discourse \& Communication, 8(1), 85-103. https://doi.org/10.1177/1750481313503221

Henry, A. \& Roseberry, R. L. (2001). A narrow-angled corpus analysis of moves and strategies of the genre: 'Letter of Application'. English for Specific Purposes, 20(2), 153-167. https://doi.org/10.1016/S0889-4906(99)00037-X

Hemsley-Brown, J. (2012). The best education in the world: reality, repetition, or cliche? international students' reasons for choosing an English university. Studies in Higher Education, 37(8), 1005-1022. https://doi.org/10.1080/03075079.2011.562286

Holmes, R. (1997). Genre analysis, and the social sciences: an investigation of the structure of research article discussion sections in three disciplines. English for Specific Purposes, 16(4), 321-337. https://doi.org/10.1016/S0889-4906(96)00038-5

Hyland, K. (2005). Stance and engagement: a model of interaction in academic discourse. Discourse Studies, 7(2), 173-192. https://doi.org/10.1177/1461445605050365

Hyland, K. (2006). English for academic purposes: an advanced resource book. Routledge.

Hyland, K., \& Tse, P. (2009). The leading journal in its field: evaluation in journal descriptions. Discourse Studies, 11(6), 703-720. https://doi.org/10.1177/1461445609347234

Kotler, P. \& Murphy, P. (1981). Strategic planning for higher education. The Journal of Higher Education, 52(5), 470-489. https://doi.org/10.1080/00221546.1981.11778119

Li, L. \& Ge, G. (2009). Genre analysis: Structural and linguistic evolution of the Englishmedium medical research article (1985-2004). English for Specific Purposes, 28(2), 93-104. https://doi.org/10.1016/j.esp.2008.12.004

Martin, P. \& Leon-Perez, I. K. (2014). Convincing peers of the value of one's research: a genre analysis of rhetorical promotion in academic texts. English for Specific Purposes, 34(1), 1-13. https://doi.org/10.1016/J.ESP.2013.09.002

Martin, J. R. (1984). Language, register and genre. Children Writing: Reader, 1, 21-30. 
Morphew, C. C., \& Hartley, M. (2006). Mission statements: a thematic analysis of rhetoric across international type. The Journal of Higher Education, 77(3), 456-471. https://doi.org/10.1080/00221546.2006.11778934

Osman, H. (2008). Re-branding academic institutions with corporate advertising: a genre perspective. Discourse and Communication, 2(1), 57-77. https://doi.org/10.1177/1750481307085577

Ozdem, G. (2011). An analysis of the MS and VS on the strategic plans of higher education institutions. Educational Sciences: Theory \& Practice, 11(4), 1887-1894. https://files.eric.ed.gov/fulltext/EJ962679.pdf

Raynor, M. E. (1998). That vision thing: do we need it? Long Range Planning, 31(3), 368-376. https://doi.org/10.1016/S0024-6301(98)80004-6

Santoro, N. \& Snead, S.L. (2013). I am not a real academic: A career from industry to academia. Journal of Further and Higher Education, 37(3), 384-396. https://doi.org/10.1080/0309877X.2011.645457

Seeber, M., Barberio, V., Huisman, J., \& Mampaey, J. (2019). Factors affecting the content of universities' mission statements: an analysis of the United Kingdom higher education system. Studies in Higher Education, 44(2), 230-244. https://doi.org/10.1080/03075079.2017.1349743

Swales, J. M. (2004). Research genres: explorations and application. Cambridge University.

Swales, J. M. \& Feak, C. B. (2012). Academic writing for graduate students: essential tasks and skills $\left(3^{\text {rd }}\right.$ Ed.). University of Michigan.

Swales, J. M., \& Rogers, P. S. (1995). Discourse and the projection of corporate culture: the mission statement. Discourse and Society, 6(2), 223-242. https://doi.org/10.1177/0957926595006002005

Tse, P., \& Hyland, K. (2009). Discipline and gender: constructing rhetorical identity in book reviews. In: Hyland K., Diani G. (eds). Academic Evaluation, 105-121. Palgrave Macmillan. https://doi.org/10.1057/9780230244290_7

Woodall, T. Hiller, A., \& Resnick, S. (2014). Making sense of higher education: students as consumers and the value of the university experience. Studies in Higher Education, 39(1), 48-67. https://doi.org/10.1080/03075079.2011.648373

Xiong, T. (2012). Discourse and marketization of higher education in China: the genre of advertisements for academic posts. Discourse \& Society, 23(3), 318-337. https://doi.org/10.1177/0957926511433786

Yang, W. (2013). Why choose us? texts in university websites: a genre analysis. Taiwan International ESP Journal, 5(1), 45-80. 